Article Type: Original Article

\title{
Orexigenic Gene Expression in Late Gestation Ovine Fetal Hypothalamus is Sensitive to Maternal Undernutrition and Realimentation
}

\author{
C.L. Adam, P. A. Williams, J. S. Milne, R. P. Aitken and J. M. Wallace \\ Rowett Institute of Nutrition and Health, University of Aberdeen, Bucksburn, Aberdeen, AB21 \\ 9SB, $U K$
}

Short title: Nutrition influences orexigenic genes in fetal hypothalamus

Key words: neuropeptide Y, agouti-related peptide, leptin receptor, arcuate nucleus, fetus

\section{Corresponding author:}

Dr Clare L Adam

Rowett Institute of Nutrition \& Health

University of Aberdeen

Bucksburn

Aberdeen

AB21 9SB

UK

Tel: +441224 438658

Fax: +44 1224438699

Email: c.adam@abdn.ac.uk

This article has been accepted for publication and undergone full peer review but has not been through the copyediting, typesetting, pagination and proofreading process, which may lead to differences between this version and the Version of Record. Please cite this article as doi: $10.1111 /$ jne. 12302

This article is protected by copyright. All rights reserved. 


\begin{abstract}
Adverse nutritional effects on developing fetal hypothalamic appetitive pathways may contribute to programmed hyperphagia and obesity in intra-uterine growth-restricted, low birth weight offspring. Here, for the first time, hypothalamic gene expression for primary orexigenic and anorexigenic genes was examined in late gestation ovine fetuses (130 days; term $=145$ days) whose mothers were undernourished $(\mathrm{UN})$ or well-nourished $(\mathrm{C})$ throughout pregnancy, or transferred from UN to C on day 90 (UN-C). Pregnancies resulted from singleton embryo transfer into adolescent growing ewes. Body weight, carcass fat content and perirenal adipose tissue (PAT) mass were all lower for UN $(n=9)$ than $C(n=7)$ and intermediate for UN-C fetuses $(n=6)$, with no effect of gender. PAT leptin gene expression (by RT-PCR) was lower in UN than C and UN-C groups, and lower in males than females. Gene expression (by in situ hybridisation with radiolabelled riboprobes) in the arcuate nucleus was greater in UN than C fetuses for neuropeptide Y (NPY), agouti-related peptide (AGRP) and leptin receptor (OBRb) but not different for pro-opiomelanocortin and cocaine- and amphetamine-regulated transcript. Gene expression in UN-C fetuses was intermediate for NPY and AGRP and not different from C fetuses for OBRb. Gene expression for NPY, AGRP and OBRb correlated negatively with fetal carcass fat content and with PAT leptin gene expression across all groups. Males had greater mRNA expression for AGRP than females, with NPY and OBRb showing similar trends. Therefore maternal undernutrition throughout pregnancy increased orexigenic gene expression in the late gestation fetal hypothalamus, and expression levels were largely normalised by improved maternal nutrition in the last third of pregnancy. These findings may have implications for avoiding or correcting prenatal programming of postnatal hyperphagia and obesity.
\end{abstract}

This article is protected by copyright. All rights reserved. 


\section{Introduction}

Over the past decade one of the underlying mechanisms thought to contribute to the fetal programming of obesity has been the nutritionally-altered expression of developing hypothalamic appetitive pathways (1). Using sheep, which share similar hypothalamic neuronal maturity at birth to the human, it was established that fetuses had adult-like hypothalamic localisation of primary orexigenic and anorexigenic genes from mid gestation onwards (2). Subsequent studies by our group demonstrated clear effects of an increased fetal nutrient supply specifically on anorexigenic gene expression. Thus pro-opiomelanocortin (POMC) and cocaine- and amphetamine-regulated transcript (CART) mRNA expression levels in the arcuate nucleus were increased along with increased fetal glycaemia in mid gestation (3), a 10-day intrafetal glucose infusion increased POMC mRNA in late gestation (4) and increased maternal and hence fetal glucose concentrations in late gestation were associated with increased CART mRNA (5). Furthermore, maternal overnutrition in late pregnancy increased POMC mRNA expression levels in offspring at 30 days of age (6).

Other laboratories investigating factors that influence hypothalamic gene expression in sheep fetuses have looked at periconceptional undernutrition (7) and/or effects on the hypothalamopituitary-adrenal axis $(8,9)$ or on epigenetic changes in fetal hypothalamic POMC and glucocorticoid receptor genes (10). An early ovine study reported increased orexigenic neuropeptide Y (NPY) mRNA levels in the mediobasal fetal hypothalamus after maternal undernutrition during just the last third of gestation (11). However, there are no published sheep studies on the effect of undernutrition throughout pregnancy, or undernutrition followed by improved maternal nutrition, on late gestation expression of the primary orexigenic and anorexigenic hypothalamic genes.

This article is protected by copyright. All rights reserved. 
Maternal undernutrition throughout gestation in a non-human primate, the baboon, resulted in increased NPY and decreased POMC immunoreactivity in the hypothalamic arcuate nuclei of term fetuses (12). It is therefore hypothesised that maternal undernutrition from conception onwards would result in an increased orexigenic and decreased anorexigenic balance of hypothalamic neuropeptide and receptor gene expression in late gestation sheep fetuses. It is further hypothesised that these expression levels may be normalised by improved maternal nutrition during the last third of pregnancy. This is worthy of investigation since altered hypothalamic appetite-regulatory gene expression in fetal life has been linked with altered growth and body composition in intra-uterine growth restricted (IUGR) offspring of undernourished rodent mothers (13). It would be relevant to both human obesity and agricultural livestock production to ascertain whether the adverse effects of IUGR may be reversed in utero by an improvement in maternal nutrition.

Recently our group reported a dominant effect of gender on postnatal (77 days) hypothalamic gene expression, with orexigenic genes predominating in males and anorexigenic genes in females (14). It is pertinent therefore to investigate whether these differences are manifest in utero. Gender-specific effects of maternal energy restriction on neonatal hypothalamic anorexigenic gene expression have been reported in an obese swine model (15). Furthermore, in a comprehensive review of developmental programming models, Aiken and Ozanne (16) conclude that sex differences in offspring outcomes are common but have been given little consideration in most studies to date.

Finally, Breton (17) concluded that the hypothalamo-adipose axis is a key target of developmental programming by maternal nutritional manipulation, mediated by a number of putative mechanisms including altered circulating leptin concentrations. Late gestation ovine 
fetuses whose mothers were undernourished throughout pregnancy were small with decreased adipose tissue development whereas those whose mothers had been changed for the last third of gestation onto improved nutrition showed partial recovery of body weight and adiposity (18). Here we additionally record changes in their adipose tissue leptin gene expression (as proxy for circulating leptin concentrations) and examine their corresponding hypothalamic orexigenic and anorexigenic gene expression.

\section{Materials and methods}

Animals, treatments and sample collection

All procedures were licensed under the UK Animals (Scientific Procedures) Act 1986 and approved by local Ethical Review. Details of the experimental design and dietary treatments have been presented previously (18). Singleton pregnancies were established using a single sire and embryo transfer from a small number of superovulated donors in order to maximise genetic homogeneity of the fetuses. Briefly, day 4 embryos were transferred synchronously into primiparous adolescent recipients of equivalent age, weight and adiposity and pregnancy was later confirmed by ultrasonography. From immediately following embryo transfer they were individually given either optimal control $(\mathrm{C} ; \mathrm{n}=8)$ or low quantity $(\mathrm{UN}, \sim 70 \%$ control; $\mathrm{n}=17$ ) of the same complete diet. The $\mathrm{C}$ dietary level aimed to provide $100 \%$ nutrient requirements of the adolescent (growing) sheep carrying a singleton fetus according to stage of pregnancy (19). The UN dietary intake was adjusted weekly after body weight measurements in order to maintain ewe body weight at the initial value, thereby depleting maternal reserves throughout gestation at the expense of the developing conceptus. At gestation day 90, a representative group of UN ewes was transferred to the C level of intake (UN-C; $\mathrm{n}=7)$. At gestation day 130 (term = 145 days) all ewes were killed by i.v. sodium pentobarbitone (20ml Euthesate; 200mg pentobarbitone/ml; Willows Francis Veterinary, 
Crawley, UK) and exsanguination. The fetus was removed and euthanised by intracardiac sodium pentobarbitone ( $3 \mathrm{ml}$ Euthesate); it was dried and weighed and the whole brain was removed, snap-frozen in isopentane chilled by liquid nitrogen and stored at $-80^{\circ} \mathrm{C}$. Perirenal adipose tissue (PAT) was dissected out, weighed and stored at $-80^{\circ} \mathrm{C}$. The fat content of the fetal carcass was determined by chemical analysis (20). Late gestation fetuses were thereby obtained from the three nutritional groups $\mathrm{C}(\mathrm{n}=8)$, UN $(\mathrm{n}=10)$ and $\mathrm{UN}-\mathrm{C}(\mathrm{n}=7)$.

\section{PAT leptin gene expression}

Messenger RNA for leptin in fetal PAT was measured by quantitative real-time RT-PCR using methods described in detail elsewhere (21). Quantification was performed using a relative standard curve method with serial dilutions of reference standard cDNA generated from RNA pooled from PAT of fetuses from each group. Individual mRNA levels are expressed relative to the sample's own internal 18S RNA.

\section{Hypothalamic gene expression}

Unfortunately three of the brains could not be sectioned due to their fragile nature and had to be excluded from gene expression study. The data are therefore analysed and presented for $\mathrm{n}$ $=7 \mathrm{C}$ fetuses ( 3 male, 4 female $), \mathrm{n}=9 \mathrm{UN}$ ( 5 male, 4 female $)$ and $\mathrm{n}=6 \mathrm{UN}-\mathrm{C}$ ( 2 male, 4 female). The frozen brains were trimmed down to a mid-ventral block, mounted and sectioned by cryostat coronally through the hypothalamus from the mammillary body (caudal) to the optic chiasm (rostral). Sections $(20 \mu \mathrm{m})$ were thaw-mounted onto poly-Llysine-coated slides and stored at $-80^{\circ} \mathrm{C}$. Gene expression for NPY, agouti-related peptide (AGRP), POMC, CART and leptin receptor (OB-Rb) was measured by in situ hybridisation, using techniques and probes described in detail previously and validated in both adult and fetal sheep brains (2-5,22-26). Briefly, sections were fixed, acetylated, and hybridised 
overnight at $58{ }^{\circ} \mathrm{C}$ using ${ }^{35} \mathrm{~S}$-labelled cRNA antisense probes $\left(1-1 \cdot 5 \times 10^{7} \mathrm{cpm} / \mathrm{ml}\right)$. They were then treated with RNase A, desalted, with a final high stringency wash (30 min) in $0 \cdot 5$ X SSC at $60{ }^{\circ} \mathrm{C}$, dried and apposed for 7 days to Kodak BioMax MR-1 film (GE Healthcare Life Sciences, Little Chalfont, Bucks, UK). Intensity and total area of hybridisation were quantified in the hypothalamic arcuate nucleus on each autoradiographic image, by an operator blind to the treatment groups, using Image-Pro Plus software (Media Cybernetics, Silver Spring, MD, USA). The integrated intensity of the hybridisation signal (i.e. the optical density integrated over the total hybridisation area) was computed using standard curves generated from ${ }^{14} \mathrm{C}$ autoradiographic micro-scales (GE Healthcare Life Sciences). For each probe, up to 6 sections spanning the medial hypothalamus (i.e. in the region midway between the mammillary body and optic chiasm, further identified by third ventricle morphology) were examined from each brain. All reagents were obtained from Sigma-Aldrich (SigmaAldrich Company Ltd., Poole, Dorset, UK) unless otherwise stated.

Statistical analyses

Effects of nutritional/diet group, gender and their interaction were examined by analysis of variance (General Linear Model; Minitab 16, Minitab Inc., State College, PA), with Tukey's post-hoc comparisons. Pearson product-moment correlation analysis was used to explore relationships between variables where indicated (Minitab 16). Statistical significance was taken as $\mathrm{P}<0.05$, and a trend is indicated where $\mathrm{P}=0.06$ to 0.10 .

\section{Results}

Fetal body weight, adiposity and PAT leptin gene expression Body weight $(\mathrm{P}<0.01)$, carcass fat content $(\mathrm{P}<0.05-0.001)$ and PAT mass $(\mathrm{P}<0.01)$ were all lower for UN versus $\mathrm{C}$ and intermediate for $\mathrm{UN}-\mathrm{C}$ fetuses (Table 1). There were no

This article is protected by copyright. All rights reserved. 
significant differences between the sexes (all $\mathrm{P}>0.20$ ) or any diet $\mathrm{x}$ sex interactions. There was a trend for PAT leptin mRNA per unit tissue, expressed relative to $18 \mathrm{~S}$, to be lower in $\mathrm{UN}$ versus $\mathrm{UN}-\mathrm{C}$ and intermediate in $\mathrm{C}$ fetuses $(\mathrm{P}=0.06)$ and there was an additional effect of sex (females $>$ males, $\mathrm{P}<0.05$ ) but no diet $\mathrm{x}$ sex interaction. In view of the differences in PAT mass, and in order to provide comparative estimates of overall PAT leptin secretion (and hence circulating concentrations), relative amounts of leptin:18S mRNA per PAT depot were calculated; these were significantly lower in UN than in $\mathrm{UN}-\mathrm{C}$ and $\mathrm{C}$ fetuses $(\mathrm{P}<0.01)$, with females $>$ males $(\mathrm{P}<0.05)$ and no interaction $($ Table 1$)$.

Hypothalamic gene expression

Gene expression in the arcuate nucleus for NPY $(\mathrm{P}<0.05)$ and AGRP $(\mathrm{P}<0.01)$ was greater in $\mathrm{UN}$ versus $\mathrm{C}$ fetuses and was intermediate and not significantly different from either UN or $\mathrm{C}$ in the UN-C fetuses (Figs 1 and 2). OBRb gene expression was also greater in UN versus $\mathrm{C}(\mathrm{P}<0.05)$ but equivalent in $\mathrm{C}$ and $\mathrm{UN}-\mathrm{C}$ fetuses (Fig. 2). Males had greater expression levels than females for NPY (trend, $\mathrm{P}<0.06)$, AGRP $(\mathrm{P}<0.05)$ and OBRb (trend, $\mathrm{P}<0.09)$. There were no differences between diet groups or sexes for CART and POMC gene expression, and no diet $\mathrm{x}$ sex interactions for any of the genes examined.

There were significant negative correlations between the carcass fat content (\%) and gene expression levels of NPY $(\mathrm{P}<0.01)$, AGRP $(\mathrm{P}<0.01)$ and OBRb $(\mathrm{P}<0.001)$, and positive correlation between carcass fat and POMC mRNA ( $<<0.05$; Fig. 3). Carcass fat $(\%)$ and relative leptin:18S mRNA content per PAT depot were correlated $(r=0.476, \mathrm{P}<0.05)$. Thus there were negative correlations between relative leptin:18S mRNA content per PAT depot and gene expression levels of NPY $(\mathrm{P}<0.001)$, AGRP $(\mathrm{P}<0.05)$ and OBRb $(\mathrm{P}<$ 0.01), but not POMC (Table 2). In addition, mRNA expression levels for NPY correlated 
positively with those for AGRP $(\mathrm{P}<0.001)$ and OBRb $(\mathrm{P}<0.01)$, and AGRP with OBRb $(\mathrm{P}$ $<0.001)$, and there were trends for POMC to correlate negatively with AGRP $(\mathrm{P}=0.06)$ and OBRb $(\mathrm{P}<0.07)$ (Table 2). CART gene expression did not correlate with carcass fat, relative PAT leptin:18S mRNA content or with any of the other genes studied.

\section{Discussion}

These data show for the first time that maternal undernutrition from conception onwards results in increased orexigenic gene expression in the ovine fetal arcuate nucleus during late gestation, and that these expression levels may be normalised, at least in part, by improved maternal nutrition during the last third of pregnancy.

In this sheep model of IUGR, the use of embryo transfer reduces genotypic variation between fetuses, and limiting maternal intake in young singleton-bearing adolescents causes a gradual depletion of maternal nutrient reserves and a slowing of fetal growth (18). The 130day fetuses of undernourished mothers had significantly decreased body weight (down by 14\%), carcass fat mass (down 28\%) and PAT mass (down 27\%), while those whose mothers were transferred onto improved nutrition from day 90 had intermediate values for these parameters that were not significantly different from controls. Gene expression in the hypothalamic arcuate nucleus for the orexigenic neuropeptides NPY and AGRP and leptin receptor $\mathrm{OBRb}$ was increased by maternal undernutrition but there was no significant change for the anorexigenic neuropeptides POMC and CART. These foregoing gene expression responses to decreased nutrient supply in the late gestation fetus match those seen in the mature adult sheep (23). In contrast to the hypothalamic responses observed in overnourished fetuses, when anorexigenic rather than orexigenic genes are perturbed $(4,5)$, here orexigenic genes appeared to be more sensitive than anorexigenic genes to undernutrition. These fetuses

This article is protected by copyright. All rights reserved. 
were showing an adaptive response to low nutrient supply in utero that would potentially improve neonatal survival by increasing appetite drive and, if it persisted, would increase postnatal food intake in the longer term.

In line with the partial recovery of fetal body weight and adiposity brought about by the increased nutrient supply in utero in the UN-C group, mRNA expression levels for NPY and AGRP were partially restored and for OBRb were completely restored; and indeed, each of these orexigenic genes correlated negatively with fetal carcass fat content across all the groups. Accordingly, anorexigenic POMC mRNA expression showed a contrasting positive correlation with carcass fat. Further support for the influence of undernutrition on an increased hypothalamic orexigenic:anorexigenic balance in this model comes from the positive correlations between expression of the different orexigenic genes, NPY and AGRP, and trends towards their negative correlation with the anorexigenic gene POMC. The present findings agree with the effects of maternal undernutrition throughout gestation on increased arcuate nucleus NPY immunoreactivity in the term fetal baboon (12). They also agree with the effects of maternal undernutrition only in the last third of pregnancy on late gestation fetal hypothalamic NPY mRNA levels in sheep (11). This begs the question whether the gene expression levels observed herein at 130 days were solely dependent on the level of nutrition from 90 days onwards (i.e. the last third of pregnancy) or whether they reflected a longerterm influence of nutrition. The data support the latter scenario since both $\mathrm{C}$ and UN-C groups were receiving the same level of nutrition in the last third of pregnancy and yet orexigenic gene expression was intermediate for $\mathrm{UN}-\mathrm{C}$ between $\mathrm{UN}$ and $\mathrm{C}$ values. Furthermore, we know that hypothalamic appetitive genes are already nutritionally-sensitive by 90 days since an elevated fetal glucose supply leading up to 81 days is associated with increased POMC and CART expression (3). It is tempting to speculate that maternal

This article is protected by copyright. All rights reserved. 
undernutrition during the first 90 days of pregnancy had already stimulated increased orexigenic gene expression, which was then decreased by improved nutrition thereafter. Nutrition at all stages throughout pregnancy may be critical in determining hypothalamic appetitive gene expression in the late gestation fetus.

Circulating plasma leptin concentrations in young lambs have been shown to correlate closely with PAT leptin mRNA (27). Hypothalamic arcuate OBRb gene expression, along with the orexigenic genes NPY and AGRP, is characteristically increased when leptin concentrations are decreased along with decreased adiposity and/or nutrient intake in adult sheep $(23,28)$ and other species $(29,30)$. Here, decreased leptin gene expression in the PAT depot was indicative of decreased leptin concentrations in the late gestation fetuses of undernourished compared with currently well-fed mothers, possibly driving the observed adult-like responses in the fetal hypothalamic appetitive pathways. In support, there were negative relationships between OBRb, NPY and AGRP gene expression and both fetal fat content and relative leptin gene expression in the PAT depot. Nonetheless, whether or not driven by changes in leptin concentrations, the restoration of orexigenic expression levels by improved nutrition for undernourished fetuses is a potentially important observation since adverse postnatal metabolic consequences of prenatal undernutrition have been linked to programmed increased orexigenic drive. Thus the increased food intake, rapid catch-up growth and adult obesity seen in IUGR offspring of undernourished mothers are associated with an increased hypothalamic orexigenic to anorexigenic gene expression ratio in rodent models (13). Here we have shown similar IUGR-induced changes in fetal hypothalamic gene expression in sheep but also partial reversal or prevention of these changes during gestation by improved maternal nutrition. It is pertinent that the longer gestation period of precocial species like sheep and human, compared with rodents, allows sufficient time for the latter.

This article is protected by copyright. All rights reserved. 
Clearly it would be beneficial if IUGR due to poor maternal nutrition could be detected early in utero and the nutritional corrections implemented before birth, leading to a healthier postnatal metabolic phenotype.

The effect of gender on hypothalamic gene expression was only significant in this study for AGRP, but similar trends were evident for NPY and OBRb. This tendency for increased orexigenic mRNA expression in males compared with females observed prenatally was similar to the significant differences observed postnatally (14). The hypothalamic sex differences herein may have been greater if there had been larger differences in body composition between the groups, since those observed in the postnatal hypothalamus were associated with marked sex differences in adiposity and leptin concentrations (females > males; 14). However, although PAT mass and carcass fat percentage were not significantly different between the sexes, PAT leptin gene expression was already greater in the female fetuses, indicative of higher leptin concentrations. The present significant relationships between orexigenic/anorexigenic gene expression in the fetal hypothalamus and fetal adiposity may herald the emergence of greater gender differences within the hypothalamic appetite circuitry which will develop further as adiposity characteristically diverges between the sexes postnatally.

Therefore, this study has revealed three novel findings in the late gestation ovine fetal hypothalamus that may also apply to the similarly precocial human: (i) adult-like responses by primary orexigenic genes (NPY, AGRP, OBRb) to nutrient deficit, (ii) the ability to normalise such changes by improved nutrition in utero, and (iii) a trend towards gender divergence with males tending to have greater orexigenic gene expression than females.

This article is protected by copyright. All rights reserved. 
These findings may have implications for avoiding or correcting prenatal programming of postnatal hyperphagia and obesity.

\section{Acknowledgements}

Research funded by the Scottish Government's Rural and Environment Science and Analytical Services Division (RESAS), including the Strategic Partnership for Animal Science Excellence (SPASE). The authors have no conflicts of interest to declare.

\section{References}

1. Mühlhäusler BS, Adam CL, McMillen IC. Maternal nutrition and the programming of obesity: the brain. Organogenesis 2008; 4: 144-152.

2. Mühlhäusler BS, McMillen IC, Rouzaud G, Findlay PA, Marrocco EM, Rhind SM, Adam CL. Appetite regulatory neuropeptides are expressed in the sheep hypothalamus before birth. J Neuroendocrinol 2004; 16: 502-507.

3. Adam CL, Findlay PA, Chanet A, Aitken RP, Milne JS, Wallace JM. Expression of energy balance regulatory genes in the developing ovine fetal hypothalamus at midgestation and the influence of hyperglycemia. Am J Physiol Regul Integr Comp Physiol 2008; 294: R1895-1900.

4. Mühlhäusler BS, Adam CL, Marrocco EM. Findlay PA, Roberts CT, McFarlane JR, Kauter KG, McMillen IC. Impact of glucose infusion on the structural and functional characteristics of adipose tissue and on hypothalamic gene expression for appetite regulatory neuropeptides in the sheep fetus during late gestation. J Physiol 2005; 565.1: 185-195.

5. Adam CL, Bake T, Findlay PA, Milne JS, Aitken RP, Wallace JM. Effects of altered glucose supply and adiposity on expression of hypothalamic energy balance

This article is protected by copyright. All rights reserved. 
regulatory genes in late gestation growth restricted ovine fetuses. Int J Dev Neurosci 2011; 29: 775-781.

6. Mühlhäusler BS, Adam CL, Findlay PA, Duffield JA, McMillen IC. Increased maternal nutrition alters development of the appetite-regulating network in the brain. FASEB J 2006; 20: 1257-1259.

7. Stevens A, Begum G, Cook A, Connor K, Rumball C, Oliver M, Challis J, Bloomfield F, White A. Epigenetic changes in the hypothalamic proopiomelanocortin and glucocorticoid receptor genes in the ovine fetus after periconceptional undernutrition. Endocrinology 2010; 151: 3652-3664.

8. Rumball CW, Oliver MH, Thorstensen EB, Jaquiery AL, Husted SM, Harding JE, Bloomfield FH. Effects of twinning and periconceptional undernutrition on lategestation hypothalamic-pituitary-adrenal axis function in ovine pregnancy. Endocrinology 2008; 149: 1163-1172.

9. Edwards LJ, McMillen IC. Impact of maternal undernutrition during the periconceptional period, fetal number, and fetal sex on the development of the hypothalamo-pituitary adrenal axis in sheep during late gestation. Biol Reprod 2002; 66: $1562-1569$.

10. Begum G, Stevens A, Smith EB, Connor K, Challis JR, Bloomfield F, White A. Epigenetic changes in fetal hypothalamic energy regulating pathways are associated with maternal undernutrition and twinning. FASEB J 2012; 26: 1694-1703.

11. Warnes KE, Morris MJ, Symonds ME, Phillips ID, Clarke IJ, Owens JA, McMillen IC. Effects of increasing gestation, cortisol and maternal undernutrition on hypothalamic neuropeptide Y expression in the sheep fetus. J Neuroendocrinol 1998; 10: $51-57$.

This article is protected by copyright. All rights reserved. 
12. Li C, McDonald TJ, Wu G, Nijland MJ, Nathanielsz PW. Intrauterine growth restriction alters term fetal baboon hypothalamic appetitive peptide balance. $J$ Endocrinol 2013; 217: 275-282.

13. Ross MG, Desai M. Developmental programming of offspring obesity, adipogenesis, and appetite. Clin Obstet Gynecol 2013; 56: 529-536.

14. Adam CL, Bake T, Findlay PA, Milne JS, Aitken RP, Wallace JM. Impact of birth weight and gender on early postnatal hypothalamic energy balance regulatory gene expression in the young lamb. Int J Dev Neurosci 2013; 31: 608-615.

15. Óvilo C, González-Bulnes A, Benítez R, Ayuso M, Barbero A, Pérez-Solana ML, Barragán C, Astiz S, Fernández A, López-Bote C. Prenatal programming in an obese swine model: sex-related effects of maternal energy restriction on morphology, metabolism and hypothalamic gene expression. Br J Nutr 2014; 111: 735-746.

16. Aiken CE, Ozanne SE. Sex differences in developmental programming models. Reproduction 2013; 145: R1-R13.

17. Breton C. The hypothalamus-adipose axis is a key target of developmental programming by maternal nutritional manipulation. J Endocrinol 2013; 216: R19R31.

18. Luther J, Aitken R, Milne J, Matsuzaki M, Reynolds L, Redmer D, Wallace J. Maternal and fetal growth, body composition, endocrinology, and metabolic status in undernourished adolescent sheep. Biol Reprod 2007; 77: 343-350.

19. AFRC (1993). Energy and Protein Requirements of Ruminants. An Advisory Manual Prepared by the AFRC Technical Committee on Responses to Nutrients. Wallingford, UK: CAB International; 1993.

This article is protected by copyright. All rights reserved. 
20. Wallace JM, Matsuzaki M, Milne J, Aitken R. Late but not early gestational maternal growth hormone treatment increases fetal adiposity in overnourished adolescent sheep. Biol Reprod 2006; 75: 231-239.

21. Matsuzaki M, Milne JS, Aitken RP, Wallace JM. Overnourishing pregnant adolescent ewes preserves perirenal fat deposition in their growth-restricted fetuses. Reprod Fertil Dev 2006; 18: 357-364.

22. Adam CL, Findlay PA, Kyle CE, Young P, Mercer JG. Effect of chronic food restriction on pulsatile luteinizing hormone secretion and hypothalamic neuropeptide Y gene expression in castrate male sheep. J Endocrinol 1997; 152: 329-337.

23. Adam CL, Archer ZA, Findlay PA, Thomas L, Marie M. Hypothalamic gene expression in sheep for cocaine- and amphetamine-regulated transcript, proopiomelanocortin, neuropeptide $\mathrm{Y}$, agouti-related peptide and leptin receptor, and responses to negative energy balance. Neuroendocrinology 2002; 75: 250-256.

24. Barrett P, Morris MA, Moar KM, Mercer JG, Davidson JA, Findlay PA, Adam CL, Morgan PJ. The differential regulation of CART gene expression in a pituitary cell line and primary cell cultures of ovine pars tuberalis cells. J Neuroendocrinol 2001; 13: $347-352$.

25. Mercer JG, Moar KM, Ross AW, Hoggard N, Morgan PJ. Photoperiod regulates arcuate nucleus POMC, AGRP, and leptin receptor mRNA in Siberian hamster hypothalamus. Am J Physiol Regul Integr Comp Physiol 2000; 278, R271-R281.

26. Mercer JG, Moar KM, Findlay PA, Hoggard N, Adam CL. Association of leptin receptor (OB-Rb), NPY and GLP-1 gene expression in the ovine and murine brainstem. Regul Pept 1998; 75-76: 271-278.

This article is protected by copyright. All rights reserved. 
27. Wallace JM, Milne JS, Aitken RP, Adam CL. Influence of birth weight and gender on lipid status and adipose tissue gene expression in lambs. J Mol Endocrinol 2014; 53:131-144.

28. Archer ZA, Rhind SM, Findlay PA, Kyle CE, Thomas L, Adam CL. Contrasting effects of constant body adiposity and increasing food intake on LH secretion and hypothalamic gene expression in sheep J Endocrinol 2002; 175: 383-393.

29. Baskin DG, Hahn TM, Schwartz MW. Leptin sensitive neurons in the hypothalamus. Horm Metab Res 1999; 31: 345-350.

30. Ahima RS, Hileman SM. Postnatal regulation of hypothalamic neuropeptide expression by leptin: implications for energy balance and body weight regulation. Regul Pept 2000; 92: 1-7.

Fig. 1. Hypothalamic orexigenic gene expression. Example autoradiographic images of (a) NPY and (b) AGRP riboprobe hybridisation to the arcuate nucleus in 130-day fetuses whose mothers were control-fed (C), undernourished (UN) or changed on gestation day 90 from UN to $\mathrm{C}(\mathrm{UN}-\mathrm{C})$. Bar $=2 \mathrm{~mm}$.

Fig. 2. Hypothalamic gene expression. Gene expression (g.e.) levels for (a) NPY, (b) AGRP, (c) OBRb, (d) POMC and (e) CART in the arcuate nucleus of 130-day ovine fetuses whose mothers were control-fed (C, $\mathrm{n}=7 ; 3$ male $(\mathrm{M}), 4$ female $(\mathrm{F}))$ or underfed (UN, $\mathrm{n}=9 ; 5 \mathrm{M}, 4$ F) throughout gestation, or changed from $\mathrm{UN}$ to $\mathrm{C}$ from gestation day 90 (UN-C, n = 6; $2 \mathrm{M}$, 4 F). Significance values (by ANOVA) for diet group and sex are displayed; there were no significant interactions. Diet groups labelled with a different letter are significantly different (by Tukey's post hoc comparisons). Mean values \pm SEM.

This article is protected by copyright. All rights reserved. 
Fig. 3. Relationships between hypothalamic gene expression and adiposity. Correlation between the carcass fat content (\%) and arcuate nucleus gene expression levels of (a) NPY, (b) AGRP, (c) OBRb, and (d) POMC in 130-day ovine fetuses whose mothers were controlfed $(\mathrm{C}, \mathrm{n}=7$; open symbols) or underfed (UN, $\mathrm{n}=9$; solid symbols) throughout gestation, or changed from UN to $\mathrm{C}$ from gestation day 90 (UN-C, $\mathrm{n}=6$; grey symbols). Round symbols denote females, diamond symbols denote males.

Table 1. Fetal body weight and adiposity. Body weight, carcass fat content, perirenal adipose tissue (PAT) mass and PAT leptin gene expression (relative to 18S) of 130-day ovine fetuses whose mothers were control-fed (C) or underfed (UN) throughout gestation or changed from UN to $\mathrm{C}$ from gestation day 90 (UN-C). Mean values \pm SEM.

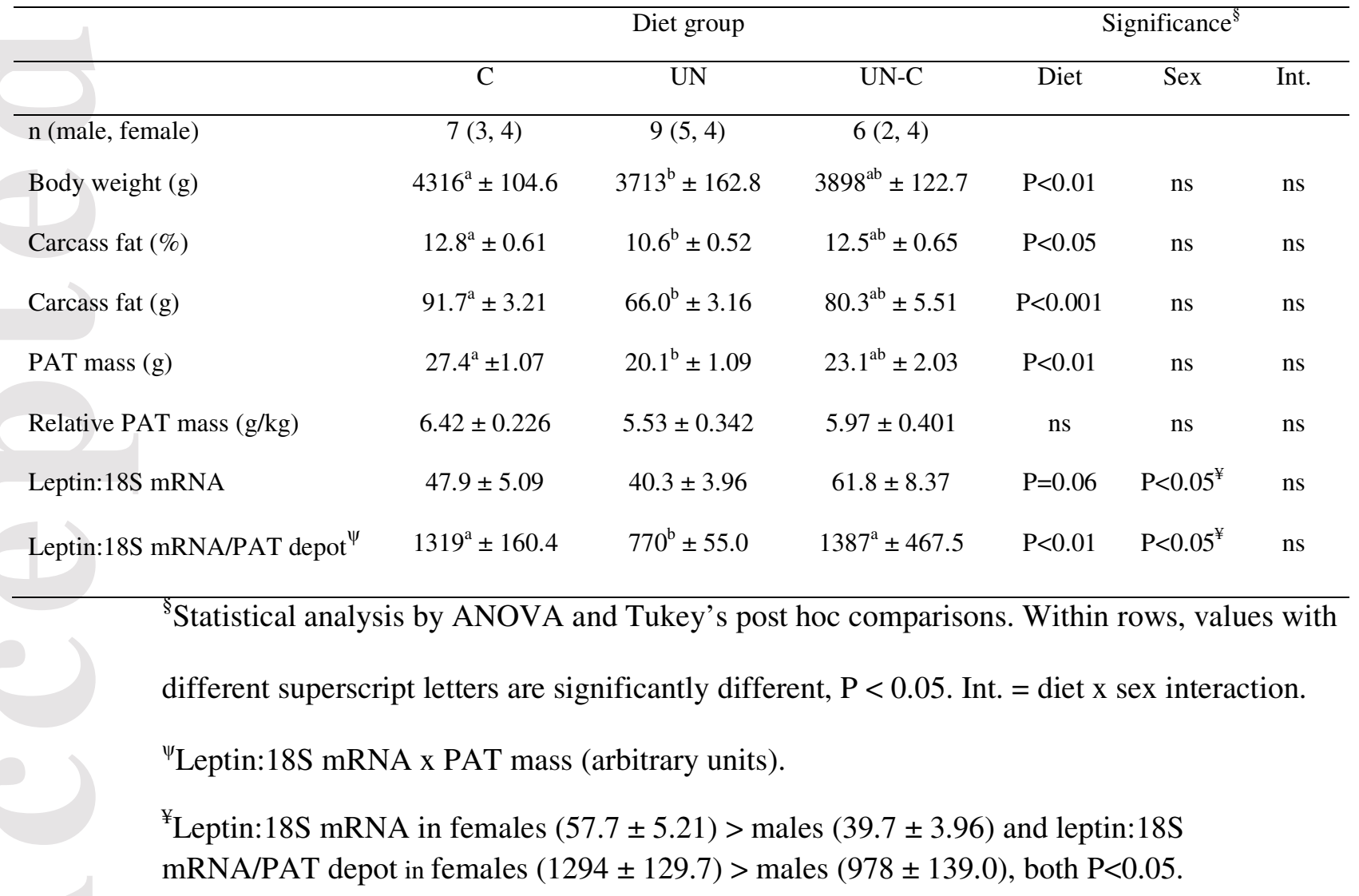

This article is protected by copyright. All rights reserved. 
Table 2. Relationships between hypothalamic genes and adipose leptin gene expression.

Correlation coefficients, and their statistical significance, for relationships between NPY,

AGRP, OBRb and POMC gene expression in the arcuate nucleus and relative total leptin:18S gene expression in the PAT depot of 130-day ovine fetuses $(n=22)$.

\begin{tabular}{lcccc}
\hline & NPY & AGRP & OBRb & POMC \\
\hline Leptin & $\mathbf{- 0 . 6 5 9}$ & $\mathbf{- 0 . 4 4 9}$ & $\mathbf{- 0 . 6 0 9}$ & 0.036 \\
& $\mathrm{P}<0.001$ & $\mathrm{P}<0.05$ & $\mathrm{P}<0.01$ & $\mathrm{~ns}$ \\
NPY & & $\mathbf{0 . 6 6 0}$ & $\mathbf{0 . 6 4 0}$ & -0.296 \\
& & $\mathrm{P}<0.001$ & $\mathrm{P}<0.01$ & $\mathrm{~ns}$ \\
AGRP & & & $\mathbf{0 . 6 6 9}$ & $\mathbf{- 0 . 4 0 1}$ \\
& & & $\mathrm{P}<0.001$ & $\mathrm{P}=0.06$ \\
OBRb & & & & $\mathbf{- 0 . 3 9 6}$ \\
& & & & $\mathrm{P}<0.07$ \\
\hline
\end{tabular}

FIG 1

C

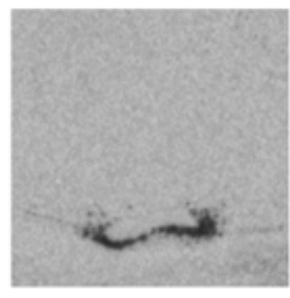

(a)

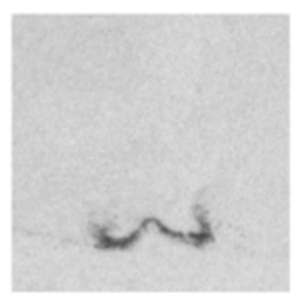

UN
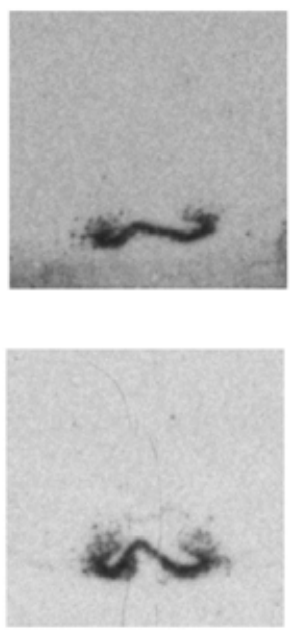

UN-C
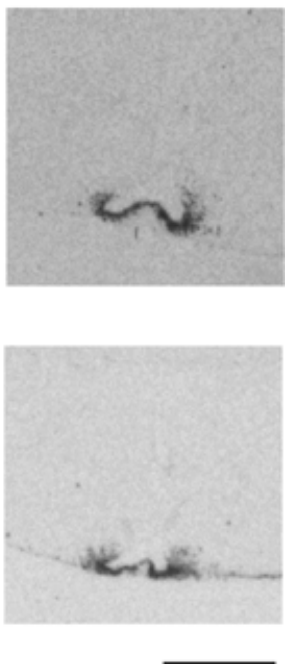

This article is protected by copyright. All rights reserved. 

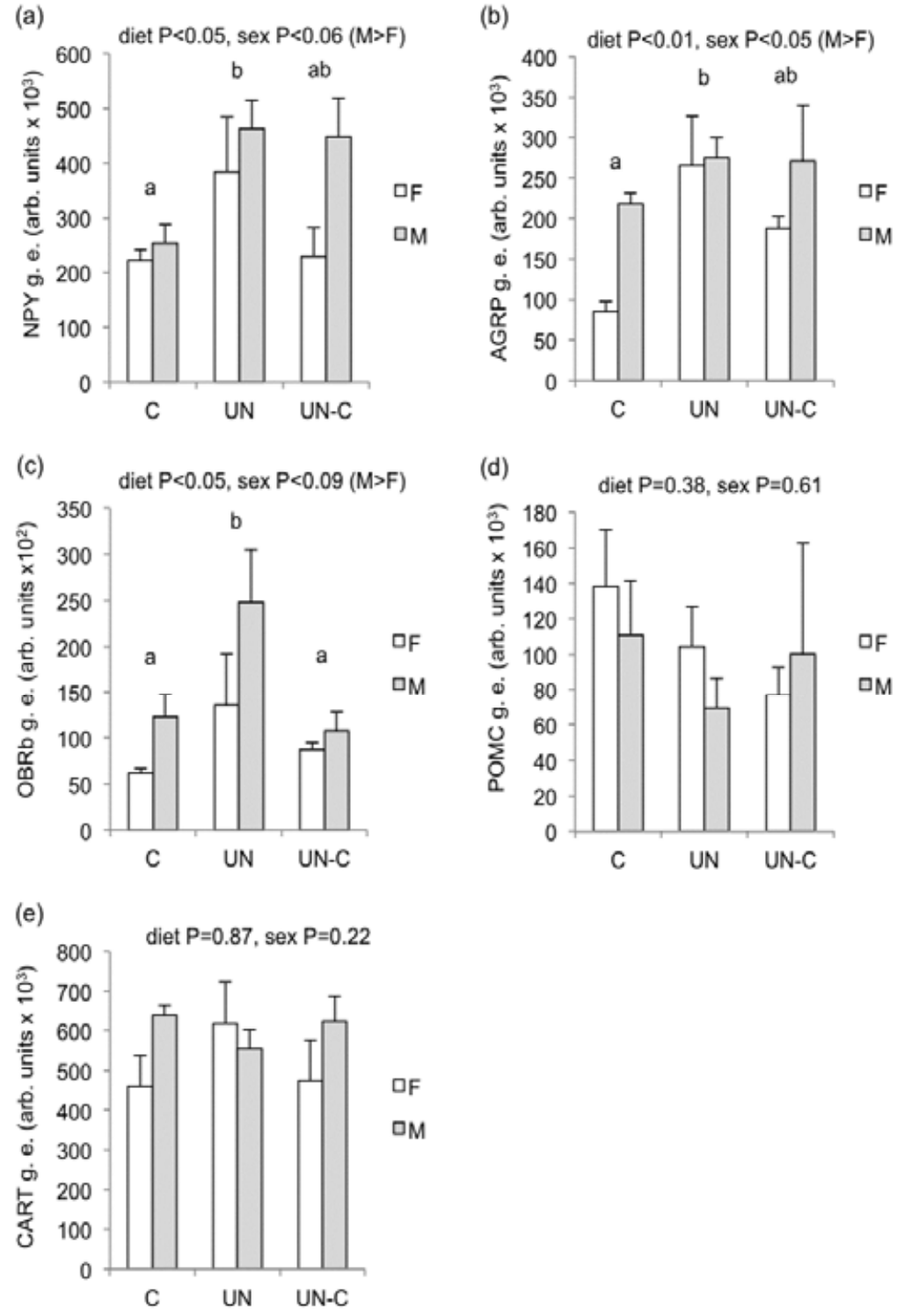

Fig. 2

This article is protected by copyright. All rights reserved. 
(a)

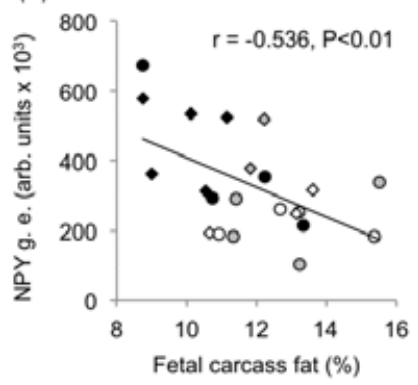

(c)

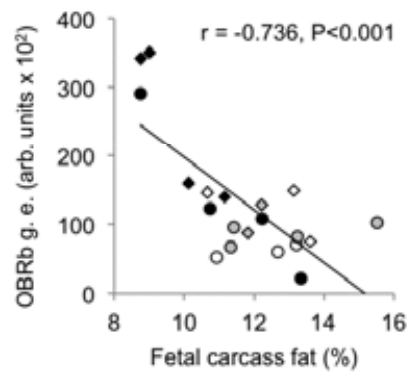

(b)

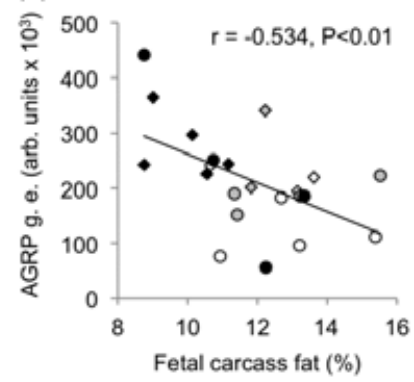

(d)

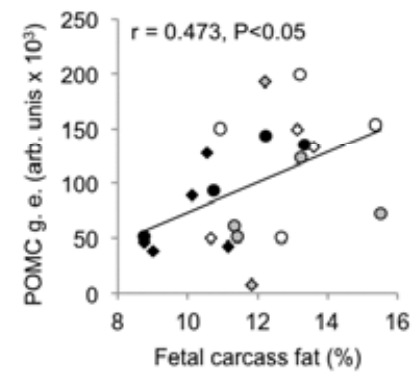

Fig. 3

This article is protected by copyright. All rights reserved. 